\title{
UPAYA MENINGKATKAN MOTIVASI BELAJAR SISWA MELALUI PENERAPAN MEDIA GAMBAR DALAM PEMBELAJARAN KOOPERATIF BAHASA INGGRIS DENGAN TEMA “TRAVELLING” DI KELAS XII MIA-3 SMA NEGERI 1 NGIMBANG LAMONGAN
}

\author{
Muslim Triono \\ m_triono64@gmail.com \\ SMA Negeri 1 Ngimbang
}

\begin{abstract}
Abstrak
Bahasa Inggris merupakan salah satu mata pelajaran wajib yang ada di sekolah. Dalam mempelajari Bahasa Inggris dengan tema "Traveling" sebagian siswa kelas XII MIA-3 SMA Negeri 1 Ngimbang Lamongan merasa kesulitan dan sangat membutuhkan media yang cocok karena dalam tema tersebut salah satunya mempelajari bagaimana mendiskripsikan tempat, dalam hal ini objek wisata. Oleh karena itu, untuk meningkatkan motivasi siswa dalam mempelajari tema "Traveling" sangat dibutuhkan sekali media yang sangat menarik, yaitu media gambar. Sehingga proses belajar dan mengajar dapat berjalan dengan lancar dan dapat mencapai hasil yang maksimal. Tujuan penelitian ini adalah untuk mengetahui : (1) apakah penerapan media gambar dapat meningkatkan motivasi belajar Bahasa Inggris dengan tema "Traveling" pada siswa kelas XII MIA-3 SMA Negeri 1 Ngimbang Lamongan, (2) bagaimana media gambar dapat diterapkan untuk meningkatkan motivasi belajar Bahasa Inggris dengan tema "Traveling" pada siswa kelas XII MIA-3 SMA Negeri 1 Ngimbang Lamongan.Subyek penelitian ini adalah siswa kelas XII MIA-3 semester genap SMA Negeri 1 Ngimbang Lamongan tahun pelajaran 2016/2017. Penelitian ini terbatas pada tema 'Travelling'. Rancangan penelitian yang digunakan adalah Penelitian Tindakan Kelas (PTK). Perangkat pembelajaran yang digunakan adalah Rencana Pelaksanaan Pembelajaran (RPP), dan Lembar Kegiatan Siswa. Sedangkan instrumen yang digunakan dalam penelitian ini adalah lembar tes hasil belajar siswa.Dari analisis data penelitian dapat disimpulkan bahwa: (1) Penerapan media gambar dapat meningkatkan motivasi belajar Bahasa Inggris dengan tema "Traveling", kesiapan belajar, pemahaman dan prestasi belajar siswa di kelas XII MIA-3 SMA Negeri 1 Ngimbang Lamongan, (2) Semangat, antusias, keceriaan dan kreativitas dalam bentuk keaktifan siswa selama proses belajar mengajar mengalami peningkatan, (3) Kemampuan siswa dalam mengungkapkan makna serta mendiskripsikan gambar mengalami peningkatan.
\end{abstract}

Kata Kunci : Motivasi Belajar, Media Gambar

\section{PENDAHULUAN}

Dalam suatu proses belajar mengajar, ada dua unsur yang sangat penting yakni metode mengajar dan media pengajaran. Kedua aspek ini saling berkaitan pemilihan salah satu metode mengajar tertentu akan mempengaruhi jenis media pengajaran yang sesuai, meskipun masih ada beberapa aspek lain yang perlu diperhatikan dalam memilih media, antara lain: tujuan pengajaran, jenis tugas dan respon yang diharapkan siswa kuasai setelah pengajarn berlangsung. Dalam proses belajar mengajar ini ada salah satu fungsi media pengajaran adalah sebagai alat bantu mengajar yang turut mempengarui, iklim, kondisi dan lingkungann belajar yang ditata dan diciptakan oleh guru.

Pembelajaran kurikulum 2013 mendasarkan pada konsep bahwa pembelajaran merupakan suatu proses pengembangan potensi dan pembangunan karakter setiap peserta didik sebagai hasil dari sinergi antara pendidikan yang berlangsung disekolah, keluarga dan masyarakat. Proses pembelajaran kurikulum 2013 tersebut memberikan kesempatan kepada peserta didik untuk mengembangkan potensi mereka menjadi kemampuan yang semakin lama semakin meningkat dalam sikap (spiritual dan 
sosial), pengetahuan, dan keterampilan yang diperlukan dirinya untuk hidup dan untuk bermasyarakat, berbangsa, serta berkontribusi pada kesejahteraan hidup umat manusia.

Menurut Direktorat Dikmenum dalam Sistem Penilaian Kurikulum 2013, nilai ketuntasan standar kompetensi ideal adalah 100, sedangkan penentuan batas pencapaian ketuntasan yang disepakati adalah skor 75 (75\% indikator atau tujuan pembelajaran), namun batas ketuntasan yang paling realistik adalah ditetapkan oleh sekolah atau daerah. Dalam kurikulum 2013 pola pembelajaran menggunakan prinsip ketuntasan secara individu. Ketuntasan belajar pada bidang studi bahasa inggris yang ditentukan oleh pihak SMA Negeri 1 Ngimbang yaitu bila siswa dalam tes hasil belajar dapat mencapai skor 75 atau lebih, maka dapat dikatakan siswa tersebut telah mencapai ketuntasan belajar.

$$
\text { Untuk mencapai tujuan }
$$

pembelajaran, di samping guru dituntut mampu mengunakan alat-alat yang digunakan, guru dituntut juga mampu mengembangkan media pembelajaran yang akan digunakan, karena media adalah bagian yang tidak terpisahkan dari proses belajar mengajar, demi tercapainya tujuan pembelajaran. Penggunaan media pengajaran dalam proses belajar mengajar dapat membangkitkan keinginan dan minat yang baru, membangkitkan motivasi dan rangsangan kegiatan belajar. Penggunaan media pengajaran dalam tahap orientasi pengajaran akan membantu keefektifan proses pembelajaran dan penyampaian pesan, isi pelajaran pada saat itu.

Media pembelajaran yang dapat digunakan dalam poroses belajar mengajar banyak sekali macamnya, salah satunya yaitu, media gambar, dimana media gambar representasi termasuk media visual yang berfungsi untuk menyalurkan pesan dari sumber ke penerima pesan, dimana pesan dituangkan melalui lambang atau symbol komunikasi visual. Menurut Arief
Sadiman (1986) simbol-simbol tersebut harus difahami benar agar proses penyampaian pesan dapat berhasil dan efisien.

Bahasa Inggris merupakan salah satu mata pelajaran wajib yang ada di sekolah. Dalam mempelajari Bahasa Inggris dengan tema "Traveling" sebagian siswa kelas XII MIA-3 SMA Negeri 1 Ngimbang Lamongan merasa kesulitan dan sangat membutuhkan media yang cocok karena dalam tema tersebut salah satunya mempelajari bagaimana mendiskripsikan tempat, dalam hal ini objek wisata. Oleh karena itu, untuk meningkatkan motivasi siswa dalam mempelajari tema "Traveling" sangat dibutuhkan sekali media yang sangat menarik, yaitu media gambar. Sehingga proses belajar dan mengajar dapat berjalan dengan lancar dan dapat mencapai hasil yang maksimal.

\section{METODE}

Kegiatan penelitian tindakan kelas ini dilaksanakan dalam beberapa siklus, proses pembelajaran pada masingmasing siklus dikenai perlakuan yang sama (langkah-langkah kegiatan yang sama), yakni terdiri dari empat tahapan dasar yang saling terkait dan berkesinambungan yaitu: (1) perencanaan, (2) pelaksanaan, (3) pengamatan, dan (4) refleksi. Setiap siklus dalam penelitian ini bertujuan untuk: mencapai tujuan penelitian yaitu untuk meningkatkan motivasi belajar siswa dengan menerapkan model pembelajaran kooperatif melalui penggunaan media gambar. Apabila pelaksanaan siklus pertama belum tercapai ketuntasan belajar maka dilakukan siklus ke dua sebagai upaya untuk perbaikan dalam pencapaian tujuan penelitian.

Peneliti membatasi penelitian ini sebanyak dua siklus karena dengan dua siklus tersebut peneliti sudah berusaha mengadakan perbaikan dalam penelitian tindakan kelas, dengan pertimbangan keterbatasan waktu yang disediakan oleh 
pihak sekolah. Apabila dalam siklus kedua motivasi belajar siswa belum berhasil ditingkatkan, maka penelitian ini akan dideskripsikan dengan alasan dan laporannya

Penelitian ini dilakukan di SMA

Negeri 1 Ngimbang Lamongan dan difokuskan pada siswa kelas XII MIA-3 pada saat mengikuti kegiatan proses belajar mengajar mata pelajaran Bahasa Inggris dengan jumlah 30 siswa dengan menerapkan media gambar untuk meningkatkan motivasi dalam mempelajari Bahasa Inggris dengan tema "Traveling".

Sebelum melakukan penelitian, peneliti terlebih dahulu merencanakan kegiatan yang dilakukan. Dari perencanaan kelas ini diharapkan kita dapat mengetahui efektifitas dari penggunaan media gambar dalam mengatasi kesulitan belajar siswa khususnya pada mata pelajaran Bahasa Inggris bagi kelas XII MIA-3. Instrumen yang digunakan dalam penelitian ini terdiri dari: Rencana Pelaksanaan Pembelajaran (RPP), Lembar Observasi, Lembar Kerja Siswa, alat-alat dokumenter, lembar/materi interview atau wawancara dan alat-alat pendukung lainnya.

Data-data yang diperlukan dalam penelitian ini diperoleh melalui (1) metode observasi terhadap pengelolaan pembelajaran melalui penerapan model pembelajaran kooperatif melalui penggunaan media gambar, observasi aktivitas siswa dan guru, dilakukan sebelum kegiatan penelitian (pra tindakan) yaitu sebagai pengumpulan data awal, serta pada saat siklus berlangsung. (2) pengukuran tes hasil belajar, dilakukan dengan tujuan mengetahui prestasi hasil belajar siswa, yang terdiri dari pengumpulan hasil akhir dengan presentase dan tulisan deskriptif gambar menggunakan Bahasa Inggris. Hasil tes ini digunakan untuk mengetahui tingkat pencapaian pemahaman siswa terhadap materi pelajaran, (3) metode dokumentasi, yaitu mencari data mengenai hal-hal atau variabel benda- benda tertulis yang berupa dokumen, transkrip, buku-buku, peraturanperaturan, catatan harian dan sebagainya. Data yang diperlukan dalam penelitian ini adalah daftar nama dan presensi. Data tersebut diperoleh dari bagiat tata usaha dan guru.

Analisis data hasil penelitian ini menggunakan teknik observasi. Analisis data merupakan cara menyusun dan mengolah data yang dikumpulkan, sehingga menghasilkan kesimpulan yang dapat dipertanggungjawabkan. Analisis data observasi yang digunakan dalam penelitian ini adalah analisis deskriptif kualitatif yaitu berusaha memaparkan data yang diperoleh dari hasil pelaksanaan tindakan yang mencakup proses dan dampak yang terjadi dari suatu siklus secara keseluruhan, selanjutnya dilakukan refleksi untuk mengkaji apa yang telah dihasilkan atau yang belum berhasil dituntaskan dengan tindakan yang telah dilakukan. Bentukbentuk analisis data observasi dalam penelitian ini meliputi :

\section{Analisis Data Observasi Siswa}

Untuk mengetahui tingkat motivasi siswa digunakan hal-hal sebagai berikut:

1) Aspek-aspek yang diamati pada masing-masing indicator motivasi belajar dapat silihat melalui lembar Kriteria Penilaian Motivasi Siswa

2) Menentukan skor siswa untuk masing-masing indicator dengan cara sebagai berikut:

a) Jika siswa memenuhi keempat aspek yang diamati, memperoleh skor 4

b) Jika siswa memenuhi 3 dari 4 aspek yang diamati, memperoleh skor 3

c) Jika siswa memenuhi 2 dari 4 aspek yang diamati, memperoleh skor 2 
d) Jika siswa memenuhi 1 dari 4 aspek yang diamati, memperoleh skor 1

e) Jika tidak memenuhi keempat aspek yang diamati, memperoleh skor 0

3) Menghitung skor motivasi ratarata pada msing-masing indikator dengan rumus:

$$
(X)=\frac{\sum \text { Skor }}{\sum \text { Siswa }}
$$

$\begin{array}{ccr}\text { Menghitung } & \text { skor } & \text { rata-rata } \\ \text { motivasi } & \text { belajar } & \text { siswa } \\ \text { dengan rumus: } & \end{array}$

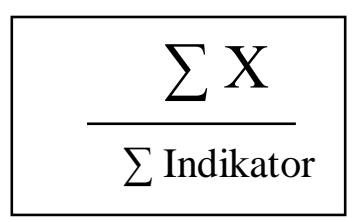

4) Menentukan kategori skor ratarata motivasi belajar siswa

\begin{tabular}{ccc}
\hline No. & Skor Rata-rata & $\begin{array}{c}\text { Kriteria Motivasi } \\
\text { Belajar } \\
\text { Sangat rendah }\end{array}$ \\
1. & $0-0,7$ & Rendah \\
. & $0,8-1,5$ & Sedang \\
3. & $1,6-2,3$ & Tinggi \\
4. & $2,4-3,1$ & Sangat tinggi \\
5. & $3,2-4$ & \\
\hline
\end{tabular}

\section{Analisis data Observasi Guru}

Menghitung jumlah skor yang diperoleh guru saat mengajar

Jumlah skor $=\sum$ Skor yang diperoleh X 100\% $\sum$ Skor maksimal

\section{PEMBAHASAN}

Penelitian ini merupakan penelitian tindakan kelas yang bertujuan untuk mengatasi permasalahan belajar siswa di dalam kelas. Permasalahan yang terjadi di kelas XII MIA-3 SMA Negeri 1 Ngimbang Lamongan tahun pelajaran 2016/2017 adalah rendahnya motivasi belajar siswa. Observasi awal sebelum tindakan menunjukkan bahwa siswa pasif dalam pembelajaran, jarang bertanya dan memberi pendapat. Siswa hanya tergantung kepada guru dan tidak mempunyai inisiatif untuk mengemukakan pendapat atau mengajukan pertanyaan. Hasil observasi yang telah dilakukan peneliti sebelum pelaksanaan tindakan adalah sebagai berikut:

\section{Rekapitulasi Hasil Observasi Motivasi Belajar Siswa} Sebelum Siklus (Pra tindakan)

\begin{tabular}{lll}
\hline No. & Aspek yang diamati & $\begin{array}{l}\text { Skor masing- } \\
\text { masing aspek }\end{array}$ \\
1. $\quad$ Minat dan perhatian & 1,8 \\
2. $\quad$ siswa terhadap pelajaran & 1,9 \\
& Semangat siswa untuk & \\
3. $\quad$ melaksanakan tugas- & 2,0 \\
4. $\quad$ tugas belajarnya & 1,8 \\
& $\quad$ Rasa senang dalam \\
& mengerjakan tugas dari \\
& guru \\
$\quad$ Reaksi yang ditunjukkan \\
$\quad$ siswa terhadap stimulus \\
$\quad$ yang diberikan guru \\
Skor rata-rata motivasi \\
belajar
\end{tabular}

Setelah melihat observasi awal tersebut, kemudian peneliti mengadakan tindakan pada siklus I dan II, yaitu dengan menerapkan pembelajaran dengan model pembelajaran kooperatif melalui penggunaan media gambar. Hasil observasi menunjukkan bahwa dengan diterapkannya pembelajaran dengan model pembelajaran kooperatif melalui penggunaan media gambar motivasi belajar siswa meningkat.

Hasil pengamatan pada siklus I, kegiatan belajar mengajar berjalan dengan baik. Siswa sangat antusias mengikuti pelajaran karena pada kegiatan awal guru menunjukkan pada siswa media gambar dalam pembelajaran Bahasa Inggris dengan tema "Traveling", yaitu gambar Candi Borubudur. Mereka sangat tertarik karena karena sebagian besar mereka mengenal candi ini dan mereka pernah mengunjunginya. Pada kegiatan inti, siswa 
lebih antusias lagi dalam mengikuti pelajaran, karena guru memberi tiap kelompok gambar yang berbeda-berbeda sehingga mereka saling berlomba-lomba untuk membuat deskripsi dengan bagus. Karena mereka bekerja dalam sebuah kelompok sehingga memudahkan mereka untuk membuat diskripsi karena mereka bisa saling berdiskusi. Selain itu didukunng pula gambar yang menarik (berwarna), jelas, serta tempat wisata yang ada digambar tersebut dikenal oleh mereka seperti gambar tugu Monas, Kebun Binatang Surabaya, dan lain-lain sehingga mereka mampu mengungkapkan makna atau mendiskripsikan tempat wisata dengan bagus dan lancar.

Analisis hasil observasi siklus I menunjukkan bahwa aspek minat dan perhatian siswa terhadap mata pelajaran semakin meningkat yang dibuktikan dengan siswa mendengarkan dan memperhatikan dengan sungguh-sungguh penjelasan dari guru, mencatat begianbagian yang penting dalam pelajaran dan aktif selama mengikuti pembelajaran. Langkah-langkah yang dapat diambil untuk memperbaiki pembelajaran yang dilaksanakan pada siklus I, yang diterpkan secara lebih intensif pada siklus II adalah guru perlu mendatangi setiap kelompok dan memberikan bantuan jika diperlukan dan memastikan setiap siswa mengetahui hasil diskusi kelompok.

Hasil observasi terhadap motivasi belajar siswa pada siklus I dapat dilihat pada tabel berikut:

\begin{tabular}{|c|c|c|c|}
\hline \multicolumn{4}{|c|}{$\begin{array}{c}\text { Rekapitulasi Hasil Observasi Motivasi Belajar } \\
\text { Siswa Siklus I } \\
\end{array}$} \\
\hline No & $\begin{array}{l}\text { Aspek yang } \\
\text { diamati }\end{array}$ & $\begin{array}{c}\text { Skor } \\
\text { masing- } \\
\text { masing } \\
\text { aspek }\end{array}$ & $\begin{array}{c}\text { Kriteria } \\
\text { Motivasi } \\
\text { Belajar }\end{array}$ \\
\hline 1. & $\begin{array}{l}\text { Minat dan } \\
\text { perhatian siswa }\end{array}$ & 2,6 & Tinggi \\
\hline 2. & $\begin{array}{l}\text { terhadap } \\
\text { pelajaran }\end{array}$ & 2,7 & Tinggi \\
\hline 3. & $\begin{array}{l}\text { Semangat siswa } \\
\text { untuk }\end{array}$ & 3,0 & Tinggi \\
\hline 4. & melaksanakan & 3,0 & Tinggi \\
\hline
\end{tabular}

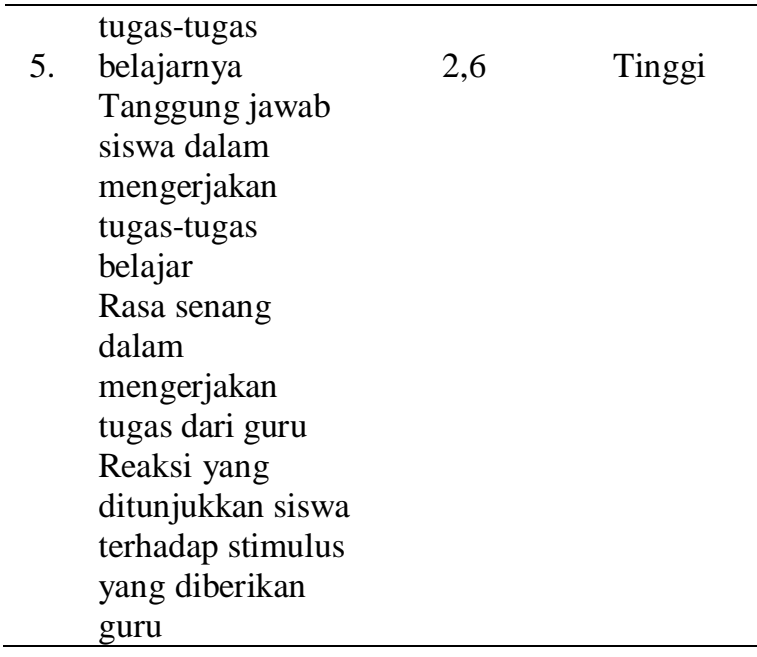

Hasil pengamatan pada siklus II, siswa lebih antusias lagi mengikuti pelajaran dibandingakn dengan siklus I. Pada kegiatan awal, guru menunjukkan sebuah gambar yang sangat menarik, yaitu gambar orang menyelam serta memberikan pertanyaan-pertanyaan seputar gambar sehingga sebelum materi disampaikan, kondisi siswa sudah fokus dan siap meneriama pelajaran. Pada awal kegitan inti, guru meminta siswa untuk bekerja dengan teman sebangkunya. Siswa sangat penasaran sekali dengan tugas apa yang akan dilakukan karena guru memberikan amplop pada skill reading maupun writing. Sehingga mereka sangat termotivasi untuk mengikuti pelajaran. Pada skill reading, tiap kelompok diminta untuk mengurutkan paragraph acak yang ada di amplop menjadi sebauh recount teks. Mereka saling berlomba cepatcepatan mengurutkan paragraph tersebut. Guru juga memberikan soal pada tiap kelompok, sehingga mereka serius mengerjakannya dan waktu untuk ngobrol dengan temannya terkurangi. Selain itu guru meminta siswa untuk menyimpulkan isi teks tersebut sehingga siswa berebut untuk menyimpulkannya. Di dalam skill Reading ini, siswa lebih paham lagi dengan teks yang diajarkan karena selain mengetahui informasi dari teks tersebut siswa juga dituntut bisa mengidentifikasi ciri dari teks recount dan mencari contoh teks recount yang lain. 
Hasil observasi terhadap motivasi belajar siswa pada siklus II dapat dilihat pada tabel berikut:

\begin{tabular}{|c|c|c|c|}
\hline \multicolumn{4}{|c|}{$\begin{array}{l}\text { Rekapitulasi Hasil Observasi Motivasi Belajar } \\
\text { Siswa Siklus II }\end{array}$} \\
\hline No & $\begin{array}{l}\text { Aspek yang } \\
\text { diamati }\end{array}$ & $\begin{array}{c}\text { Skor } \\
\text { masing- } \\
\text { masing } \\
\text { aspek }\end{array}$ & $\begin{array}{c}\text { Kriteria } \\
\text { Motivasi } \\
\text { Belajar }\end{array}$ \\
\hline 1. & $\begin{array}{lr}\text { Minat } & \text { dan } \\
\text { perhatian } & \text { siswa }\end{array}$ & 3,1 & $\begin{array}{l}\text { Sangat } \\
\text { Tinggi }\end{array}$ \\
\hline & $\begin{array}{l}\text { terhadap } \\
\text { pelajaran }\end{array}$ & 3,0 & Tinggi \\
\hline 3. & $\begin{array}{l}\text { Semangat siswa } \\
\text { untuk }\end{array}$ & 3,0 & Tinggi \\
\hline 4. & $\begin{array}{l}\text { melaksanakan } \\
\text { tugas-tugas }\end{array}$ & 3,2 & Sangat \\
\hline 5. & $\begin{array}{l}\text { belajarnya } \\
\text { Tanggung jawab } \\
\text { siswa dalam } \\
\text { mengerjakan } \\
\text { tugas-tugas } \\
\text { belajar } \\
\text { Rasa senang }\end{array}$ & 2,8 & Tinggi \\
\hline
\end{tabular}

\begin{tabular}{l}
\hline dalam \\
mengerjakan \\
tugas dari guru \\
Reaksi yang \\
ditunjukkan \\
siswa terhadap \\
stimulus yang \\
diberikan guru \\
Perolehan pada siklus II \\
menunjukkan bahwa motivasi belajar \\
siswa sudah memenuhi kriteria \\
keberhasilan yakni motivasi belajar yang \\
tinggi. Observasi siklus ke dua \\
menunjukkan motivasi belajar siswa \\
semakin meningkat. Peningatan motivasi belajar \\
Pening \\
siswa dari sebelum siklus, siklus I dan \\
siklus II dapat dilihat pada grafik berikut:
\end{tabular}

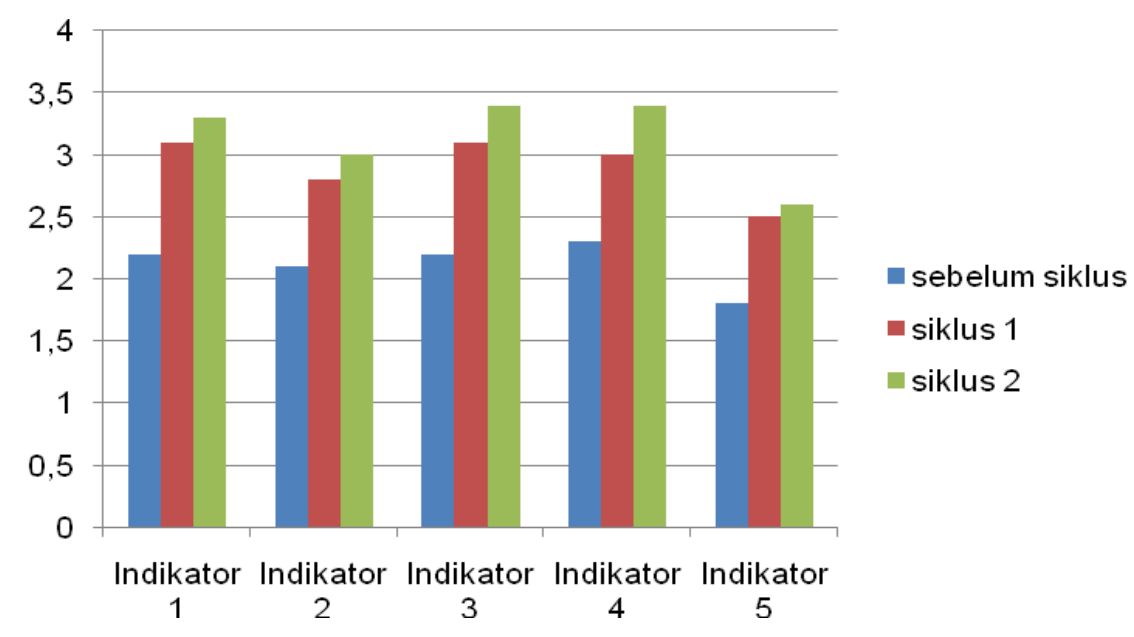

Grafik 1. Peningkatan Motivasi Belajar Siswa

Keterangan:

Indikator 1 : Minat dan perhatian siswa terhadap pelajaran

Indikator 2 : Semangat siswa untuk melaksanakan tugas-tugas belajarnya

Indikator 3 : Tanggung jawab siswa dalam mengerjakan tugas-tugas belajar

Indikator $4 \quad$ : Rasa senang dalam mengerjakan tugas dari guru

Indikator 5 : Reaksi yang ditunjukkan siswa terhadap stimulus yang diberikan guru 
Grafik diatas menunjukkan bahwa setelah diadakan tindakan pada silklus I dan siklus II, motivasi belajar siswa terus mengalami peningkatan. setelah dilakukan tindakan, indicator motivasi belajar telah tergolong pada kategori tinggi (skor $\geq 2,4$ ).

Dalam penerapan media gambar dalam pembelajaran kooperatif guru bukan hanya membuat siswa pasif, melainkan guru membimbing siswa untuk selalu aktif bertanya atau memberikan kesempatan pada siswa untuk berfikir secara aktif, kreatif, dan inovatif karena guru memberi stimulus yang direspon dengan baik oleh murid..

Berdasarkan penjelasan di atas secara umum dapat dijelaskan bahwa penerapan pembelajaran dengan model pembelajaran kooperatif melalui penggunaan media gambar dapat meningkatkan motivasi belajar siswa. Hal ini sesuai dengan penelitian yang telah dilakukan oleh Suwiyadi (dalam Jurnal Pendidikan Inovatif Volume 2, Nomor2, Maret 2007) dan Riska Nur Mujiyanti (2009) bahwa penerapan pembelajaran dengan model pembelajaran kooperatif melalui penggunaan media gambar efektif dalam meningkatkan motivasi sekaligus hasil belajar siswa.

Temuan penelitian yang
menyatakan bahwa siswa dapat

\section{KESIMPULAN}

Dari hasil serangkaian analisis data dan pembahasannya, maka dapat diambil satu kesimpulan bahwa penerapan media gambar dalam pembelajaran kooperatif bahasa Inggris dengan tema Travelling dapat meningkatkan motivasi belajar siswa kelas XII MIA-3 SMA Negeri 1 Ngimbang Lamongan.

\section{DAFTAR PUSTAKA}

A.M. Sudirman. Interaksi dan Motivasi Belajar Mengajar. Jakarta: CV. Rajawali. 1986. bekerjasama dan mengenal lebih baik anggota kelompok diskusi yang lain melalui interaksi antar anggota kelompok sesuai dengan pendapat Ekowati (2003:10) yang menyatakan bahwa siswa yang bekerja dalam situasi pembelajaran kooperatif terdorong untuk bekerjasama pada suatu tugas bersama, dan mereka harus mengkoordinasikan usahanya untuk menyelesaikan tugasnya sehingga terjalin suatu interaksi yang meningkatkan hubungan antar siswa.

Selama penerapan model pembelajaran kooperatif melalui penggunaan media gambar, siswa terlibat aktif pada jalannya diskusi kelas. Siswa tidak segan bertanya dan mengemukakan pendapat. Siswa merasa senang dan percaya diri karena setiap pendapat yang dikemukakan diberi respon positif oleh guru dan teman-temannya. Dengan demikian, berdasarkan paparan hasil-hasil penelitian di atas, maka dapat diketahui bahwa penerapan media gambar dengan model pendekatan kooperatif dalam proses pembelajaran Bahasa Inggris khususnya pada tema 'Travelling' dapat berjalan efektif dan dapat meningkatkan motivasi belajar siswa kelas XII MIA-3 SMA Negeri 1 Ngimbang Lamongan.

Asnawir, $\mathrm{H}$ dan Usman, Basyiruddin. Media Pembelajaran. Jakarta: Ciputat Pers. 2002

Depdiknas. 2006. Kurikulum Tingkat Satuan Pendidikan SMA Pedoman Pengembangan Silabus dan Penilaian. Jakarta: Depdikas

Dimyati dan Mujiono. Belajar dan Pembelajaran. Jakarta: Rineka Cipta. 1999.

Hamali oeamar. Proses belajar Mengajar. Jakarta: Bumi Akasara. 2001

Moleong, J. Lexy. Metode Penelitian Kualitatif. Bandung: PT. Remaja Rosdakarya. 2002 
Rohani, Ahmad. Media Instruksional Edukatif. Jakarta: Rineka Cipta. 1997

Soedarsono, FX. Aplikasi Penelitian Tindakan Kelas. Jakarta: PAUPPAI, Universitas terbuka. 2001

Soeparno. Media Pengajaran Bahasa. Yogyakarta: PT. Intan Pariwara. 1988

Suryosubroto, B. Proses Belajar Mengajar Di Sekolah. Jakarta: Rineka Cipta. 1997

Tim Penyusun. 1991. Kamus Besar Bahasa Indonesia. Edisi kedua. Jakarta : Balai Pustaka.

Yamin, Martinis. Strategi Pembelajaran Berbasis Kompetensi. Jakarta: Gaung Persada Press. 2004 